\title{
CLINICAL STUDY TO EVALUATE DIABETIC ULCER SEVERITY SCORE (DUSS) IN DIABETIC FOOT ULCER
}

\author{
Harindranath H. R', Ravikar Jayaraj ${ }^{2}$, Mohan Kumar $R^{3}$ \\ ${ }^{1}$ Associate Professor, Department of General Surgery, Bangalore Medical College and Research Institute, Bangalore. \\ ${ }^{2}$ Assistant Professor, Department of General Surgery, Bangalore Medical College and Research Institute, Bangalore. \\ ${ }^{3}$ Post Graduate, Department of General Surgery, Bangalore Medical College and Research Institute, Bangalore.
}

\section{ABSTRACT}

A number of diabetic foot ulcer classification is in practice for effective categorization of patients and to predict the outcome. Diabetic Ulcer Severity Score is one of the latest simple wound based score, completely a clinical score which needs to be evaluated for its effectiveness in predicting the outcome of foot ulcers in patients with diabetes.

\section{METHODS}

A total of 226 diabetic patients with foot ulcers treated as outpatient or admitted patients from 1st January to 31st December 2014 were included in the study and was followed till complete healing of ulcer or amputation or for a minimum period of 6 months. Those patients who lost for followup before 6 months were excluded from study. Necessary data was collected and DUSS was calculated at the start of treatment.

\section{RESULTS AND CONCLUSION}

In our study, patients with score 3 had higher risk (40\%) for minor amputation and those with score 4 had higher risk (21\%) for major amputation overall. Patients with score 4 had $37 \%$ risk for minor amputation. Higher the score higher is the risk for amputation and lesser the chance of healing. DUSS scoring system provides an easy diagnostic tool for predicting probability of healing or amputation by combining four clinically assessable wound based parameters namely presence or absence of pedal pulses, probing to bone, wound location and presence or absence of multiple ulcers. Study groups can be stratified depending on severity of ulcers and thus can help provide a simple, streamlined approach in clinical setting without need of any advanced investigative tool, but it does not alter the procedure of wound management. The scoring system can be easily applied to clinical practice.

\section{KEYWORDS}

Amputation, Diabetic Foot Infections, Peripheral Neuropathy, Peripheral Vascular Disease.

HOW TO CITE THIS ARTICLE: Harindranath HR, Jayaraj R, Mohan Kumar. "Clinical study to evaluate diabetic ulcer severity score (DUSS) in diabetic foot ulcer." Journal of Evolution of Medical and Dental Sciences 2015; Vol. 4, Issue 103, December 24; Page: 16827-16829, DOI: $10.14260 /$ jemds/2015/2526

\section{INTRODUCTION}

Approximately, 177 million people worldwide are diabetic. This number is likely to double by $2030 .{ }^{1}$ Diabetes is responsible for every 1 in 20 deaths from all causes and approximately four million annual deaths are because of complications of diabetes, i.e. six deaths every minute or one death every 10 seconds. ${ }^{1}$ More than 80 percent of diabetes deaths occur in low- and middle-income countries. ${ }^{2}$

India has been called "the diabetes capital of the world," and "every fifth diabetic in the world is an Indian." 3 The disease currently affects more than 62 million Indians, which is more than $7.1 \%$ of India's adult population. ${ }^{4}$ The problem of diabetes is not homogenous in India. ${ }^{5}$ Currently, 4.0-11.6 percent of India's urban population and three percent of the rural population above the age of 15 has diabetes.6,7 An estimate shows that nearly 1 million Indians die due to Diabetes every year. ${ }^{8}$ The average age of onset is 42.5 years. ${ }^{8}$ the prevalence of Impaired Glucose Tolerance Test (GTT) ranges from 3.6-9.1 percent, which indicates a potential of further increase in the prevalence. ${ }^{6}$ It is projected to increase to 70 million by 2025.7

Financial or Other, Competing Interest: None.

Submission 02-12-2015, Peer Review 03-12-2015,

Acceptance 18-12-2015, Published 22-12-2015.

Corresponding Author:

Dr. Harindranath H. R,

No.1852/3, 1st Cross,

Prakash Nagar,

Bangalore-560021.

E-mail: harindranath82@gmail.com

DOI:10.14260/jemds/2015/2526
Due to these sheer numbers, the socio-economic burden due to diabetes in India is among the highest in the world. ${ }^{9}$ The overall direct healthcare costs of diabetes mellitus ranges from 2.5-15 percent of annual health care budgets. This burden is likely to only increase with the projected increase in the number of people with diabetes. ${ }^{10}$

A Diabetic Foot is a foot that exhibits any pathology that results directly from Diabetes or any long-term (or "chronic") complications of Diabetes Mellitus. ${ }^{11}$

It is estimated that $15 \%$ of diabetics develop a foot ulcer within their lifetime and up to $70 \%$ of all non-traumatic amputations in the world occur in diabetics. ${ }^{12}$ Many of these amputations are preventable as $85 \%$ are preceded by a foot ulcer. A number of contributory factors work together to cause foot ulceration in patients with diabetes. These include peripheral neuropathy, peripheral vascular disease, foot deformities, external trauma and peripheral edema. With the exception of trauma, it is usually a combination of problems rather than a single risk factor that causes ulceration. One of the commonest combinations causing ulceration is peripheral neuropathy, foot deformity and trauma. ${ }^{13}$

Of longstanding diabetic patients, $20 \%-40 \%$ develop peripheral neuropathy. ${ }^{14}$

As many as $20 \%-40 \%$ of patients with diabetes have peripheral vascular disease and up to $50 \%$ of patients with a foot ulcer have signs of PVD. ${ }^{15}$

Foot infections in diabetic patients usually begin skin ulceration. ${ }^{16}$ although most infections remain superficial, $\sim 25 \%$ will spread contagiously from skin to subcutaneous tissues and or bone. Up to half of those who have foot infection will have another within few years. About 10\%-30\% of diabetic patients with foot ulcer will eventually progress to an 
amputation which may be minor (i.e. foot sparing) or major. Conversely ulcer precedes $\sim 60 \%$ of amputation. ${ }^{17,18,19}$ making infection most important proximate cause of this tragic outcome. During the followup period, a total of $49 \%$ of diabetic individuals with history of foot ulcer died compared with $35.2 \%$ of diabetic individuals without a history of foot ulcer. ${ }^{20}$

Since diabetic foot ulcers and amputations account for significant part of diabetic related health care costs. ${ }^{[6,7]}$ several classification systems have been proposed to help to assess the severity of disease. According to International Working Group on Diabetic Foot, a classification system appropriate for clinical practice should facilitate communication between health care providers, influence daily management and provide information about the potential healing of ulcer.[9]

In 1976, Meggit described a wound classification that was further popularized by Wagner in 1981. However, the Meggit-Wagner system exclusively assessed ulcer depth alone without considering comorbidities such as ischemia or pressure load.

\begin{tabular}{|c|c|}
\hline Grade & Description \\
\hline 0 & $\begin{array}{r}\text { Pre-ulcerative lesion, healed ulcers, } \\
\text { presence of bony deformity }\end{array}$ \\
\hline 1 & $\begin{array}{c}\text { Superficial ulcer without } \\
\text { subcutaneous tissue involvement }\end{array}$ \\
\hline 2 & $\begin{array}{r}\text { Penetration through the subcutaneous } \\
\text { tissue without abscess or osteomyelitis }\end{array}$ \\
\hline 3 & Deep ulcer with abscess or osteomyelitis \\
\hline 4 & Gangrene of fore foot \\
\hline 5 & Gangrene of entire foot \\
\hline
\end{tabular}

Presently Meggit-Wagner system is widely used.

University of Texas classification improved ulcer classification by including ischemia and infection.

Diabetic Ulcer Severity Score as described by Beckert et al. is one such new wound based classification system with score ranging from 0 to 4 using palpable pedal pulses, probing to bone, ulcer site and presence of multiple ulcers which needs to be validated.

Classification of various diabetic foot surgeries into major or minor amputations. ${ }^{21}$

\begin{tabular}{|c|c|c|}
\hline $\begin{array}{c}\text { Amputation } \\
\text { Level }\end{array}$ & $\begin{array}{c}\text { Distal or } \\
\text { Minor } \\
\text { Amputation }\end{array}$ & $\begin{array}{c}\text { Proximal or } \\
\text { Major } \\
\text { Amputation }\end{array}$ \\
\hline Fore foot & $\begin{array}{c}\text { Toe } \\
\text { Disarticulation } \\
\text { Ray } \\
\text { Transmetatarsal }\end{array}$ & \\
\hline Mid foot & $\begin{array}{c}\text { Lis franc } \\
\text { Chopart }\end{array}$ & \\
\hline Hind foot & $\begin{array}{c}\text { Syme } \\
\text { Boyd } \\
\text { Pirogoff } \\
\text { Modified Pirogoff }\end{array}$ & Below the knee \\
\hline Transtibial & & Gritti stokes \\
\hline Through the & & Above the knee \\
\hline knee & & $\begin{array}{c}\text { Hip } \\
\text { dransfemoral }\end{array}$ \\
\hline Hip & & \\
\hline
\end{tabular}

\section{METHODS AND METHODOLOGY}

The clinical study was conducted in Bowring and Lady Curzon Hospital from 1st January to 31st December 2014 attached to Bangalore Medical College and Research Institute.
A total of 226 diabetic patients with foot ulcers were studied during the period, which included both inpatient and outpatients based on inclusion and exclusion criteria. Consent was obtained from each patient after explaining study in detail.

\section{Inclusion Criteria}

1. All patients were diagnosed with Diabetes having foot ulcers.

2. Ulcers below the level of ankle.

\section{Exclusion Criteria}

1. Foot ulcers in Non-Diabetic patients.

2. Ulcers above the level of ankle.

3. Venous ulcers.

Four clinically defined parameters namely palpable pedal pulses, probing to bone, ulcer site, number of ulcers were assessed initially and Diabetic Ulcer Severity Score was calculated at the start of the study. Patients were followed up for 6 months or until healing or amputation. Those patients who lost for followup before 6 months were excluded from study.

\section{DUSS SCORING SYSTEM}

\begin{tabular}{|c|c|c|}
\hline Parameters & Score 0 & Score 1 \\
\hline Palpable pedal pulse & Yes & No \\
\hline Probing to bone & Yes & No \\
\hline Ulcer site & Toes & Foot \\
\hline Ulcer number & Single & Multiple \\
\hline
\end{tabular}

The infected ulcers were swabbed for culture and sensitivity and appropriate antibiotic therapy started as per culture and sensitivity. Surgical debridement and dressing done with either with saline gauze, povidone-iodine, hydrogel, collagenase, human recombinant derived growth factor. Patients with gangrenous tissue underwent appropriate amputations. Skin grafting done for infection free ulcers covered with healthy granulation tissue, which did not heal completely. Adequate glycemic control maintained during treatment.

\section{OBSERVATION}

\begin{tabular}{ll|}
\hline Baseline demographic details & \\
Patients & Male 139; Female 87 \\
Sex & $62(34-84)$ \\
Age (years) & $7(3-48)$ \\
Number of visits & $62(10-82)$ \\
Time of follow up (days) & 132 \\
Hospitalization & \\
Wounds & $30(15-170)$ \\
Wound history (days) & $9(1-126)$ \\
Wound area (cm 2 ) & 76 \\
Multiple ulcers & 88 \\
Soft tissue infections & \\
In initial visits & 58 \\
Probing to bone & 137 \\
Ulcer location Toe-89/ Foot- & 143 \\
Palpable pedal pulses & \\
Wound grading & 81 \\
Grade 1 & 62 \\
Grade 2 & 08 \\
Grade 3 & 15 \\
Grade 4 & 58 \\
Grade 5 & \\
Surgery & \\
Sharp debridement & 30 \\
Minor amputation & 11 \\
Major amputation &
\end{tabular}




\begin{tabular}{|c|c|c|c|c|c|c|}
\hline \multirow{2}{*}{ DUSS } & \multirow{2}{*}{$\begin{array}{c}\text { No. of } \\
\text { Patients }\end{array}$} & \multirow{2}{*}{ Debridment } & \multicolumn{2}{c|}{$\begin{array}{c}\text { Major } \\
\text { Amputation }\end{array}$} & \multicolumn{2}{c|}{$\begin{array}{c}\text { Minor } \\
\text { Amputation }\end{array}$} \\
\cline { 4 - 7 } & & & Yes & $\mathbf{\%}$ & Yes & \% \\
\hline 0 & 87 & 87 & 0 & 0 & 0 & 0 \\
\hline 1 & 51 & 51 & 0 & 0 & 0 & 0 \\
\hline 2 & 23 & 23 & 0 & 0 & 5 & 21 \\
\hline 3 & 22 & 22 & 2 & 9 & 9 & 40 \\
\hline 4 & 43 & 43 & 9 & 21 & 16 & 37 \\
\hline
\end{tabular}

In our study of 226 patients, 139 were male and 87 were female, mean age of presentation being 62 years. All patients required debridement. Patients with score 0 and 1 required debridement only. Of 23 patients with score 2, 5(21\%) underwent minor amputation and no major amputation was done in these patients; $2(9 \%)$ major amputation and $9(40 \%)$ minor amputation were performed among 22 patients with score of 3 . Of 43 patients with score $4,9(21 \%)$ required major amputation and $16(37 \%)$ required minor amputation.

\section{REFERENCES}

1. Vision Rehabilitation Centre. Diabetes and the Eye. Newsletter 12 [Document on the Internet]. Hyderabad (India): Vision Rehabilitation Centre; 2003 [cited 2013 May20].http://patientcare.lvpei.org/visionrehabilitatio n/images/light-up12.pdf.

2. World Health Organization. Diabetes. Factsheet [Document on the Internet]. Geneva: WHO; 2012 [[Updated 2013 March; cited 2013 Jun 8]. Available from:http://www.who.int/mediacentre/factsheets/fs3 12/en/index.html.

3. Joshi SR, Parikh RM. India - diabetes capital of the world: now heading towards hypertension. J Assoc Physicians India. 2007;55:323-324. [PubMed].

4. "Diabetes can be controlled in 80 percent of cases in India." IANS. News.biharprabha.com. Retrieved 6 February 2014.

5. Arora V, Malik JS, Khanna P, Goyal N, Kumar N, Singh M. Prevalence of Diabetes in urban Haryana. Australas Med J 2010;3(8):488-94.

6. Park K. Park's textbook of preventive and social medicine. 21st ed. Jabalpur: M/s Banarsidas Bhanot; 2011. Epidemiology of chronic non-communicable diseases and conditions; pp. 363-4.

7. India, world diabetes capital. Hindustan Times [Newspaper on the Internet]. 2007 Sep 03 [Cited 2013 May 25]; para 1-5. Available from: http://www.hindustantimes.com/India-worlddiabetescapital/Article1-245889.aspx.
8. Gale, Jason (November 7, 2010). "India's Diabetes Epidemic Cuts Down Millions Who Escape Poverty." Bloomberg. Retrieved 8 June 2012.

9. Joshi SR, Das AK, Vijay VJ, et al. Challenges in diabetes care in India: sheer numbers, lack of awareness and inadequate control. J Assoc Physicians India. 2008;56:443-50. [PubMed].

10. Sadikot SM. The Indian task force on diabetes care in India [Homepage on the Internet] Mumbai: Diabetes India; [Cited 2013 Jun 4]. Available from: Available from: http://www.diabetesindia.com/diabetes/itfdci.htm.Bou Iton in Diabetes, 30;36 2002.

11. Boulton AJ, Vileikyte L, Ragnarson-Tennvall G, et al. The global burden of diabetic foot disease. Lancet 2005;366:1719-1724.

12. Boulton AJ. The diabetic foot - an update. J Ankle Foot Surg 2008;14:120-124.

13. Clayton W, Elasy TA. A review of the pathophysiology, classification and treatment of foot ulcers in diabetic patients. Clinical Diabetes 2009;27(2):52-58.

14. International Consensus on the Diabetic Foot and Practical Guidelines on the Management and Prevention of the Diabetic Foot by the International Working Group on the Diabetic Foot/Consultative Section of the IDF; 2007.

15. Lipsky BA. Infectious problems of the foot in diabetic patients. In:Bowker JH, Pfeifer MA, eds. The diabetic foot. 6th ed. St. Louis: Mosby, 2001:467-80.

16. International Working Group on the Diabetic Foot. International consensus on the diabetic foot. Amsterdam, 1999;1-96.

17. Pecoraro RE, Ahroni JH, Boyko EJ, Stencil VL. Chronology and determinants of tissue repair in diabetic lowerextremity ulcers. Diabetes 1991;40:1305-13.

18. Reiber GE, Pecoraro RE, Koepsell TD. Risk factors for amputation in patients with diabetes mellitus: a case control study. Ann Intern Med 1992;117:97-105.

19. Marjolein M Iversen, Grethe S Tell, Trond Riise, et al. History of foot ulcers increases mortality among individuals with diabetics. Diabetes care. 2009 Dec;32(12):2193-2199.

20. Aziz Nather, Keng Lin Wong. Distal amputations foe diabetic foot, Diabetic Foot Ankle 2013;4:10.3402. 